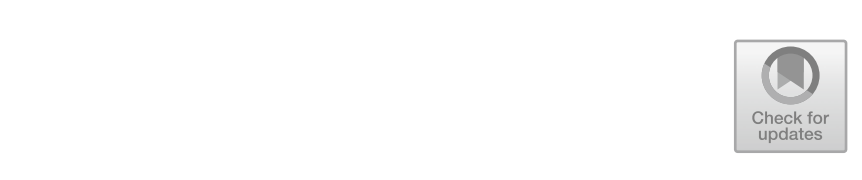

8

\title{
Other Income Sources
}

In this chapter, we stress the fact that households' incomes were complex and came together by a mix of activities. To fully understand how households managed their livelihoods, activities other than fishing, hunting, and reindeer herding also need to be considered. Bjørklund has suggested that the inhabitants' livelihood in interior Scandinavia until the nineteenth century was a continual "multifaceted household adaption" made up of a wide range of activities. ${ }^{1}$ This view has parallels to analytical concepts to understand early modern agrarian livelihoods, and the latest concept launched is an "integrated peasant economy." The concept stresses that peasants engaging in a wide number of subsistence activities was a prominent characteristic of pre-industrial farms in many regions of Europe and particularly in upland areas. Used in a Sami context, it has shown that diversification was an active and systematic choice for these households, not something they did occasionally. ${ }^{3}$ Some of these activities were for subsistence, some for exchange. However, the more engaged

\footnotetext{
${ }^{1}$ Bjørklund (2013).

2 Panjek et al. (2017).

3 Päiviö (2017).

(C) The Author(s) 2022 
users were in reindeer pastoralism, the less time they had to spend on other activities, and the more they traded.

Several means of livelihood besides herding, fishing, and hunting were part of everyday life for early modern inhabitants in interior northwest Fennoscandia. By and large, people's economy depended on self-sufficiency, so all or most of the food, clothes, and utensils they needed were produced within the household. Any excess products were sold, bartered, or used for paying tax. What households could produce was to a large extent determined by their main mode of production, which in turn was linked to rights or access to resources. Reindeer pastoralist households could thus produce a variety of reindeer products, for example, dried meat, cheese, leather and fur from hides, and wire from sinews. They also transported people, post, and goods. Much of the produced goods were used in the household, but with gradually enlarging reindeer herds, it became more and more feasible to produce a surplus to sell. Fisher households, on the other hand, produced dried fish mostly for household consumption but occasionally, when harvests were especially rich, also for sale. Many households, foremost those that dwelled in the boreal forest, hunted wild mammals and birds that contributed extra food and raw materials, such as furs, meat, feathers, and eggs. They also engaged in gathering of raw materials such as plants, bark, roots, and berries. ${ }^{4}$ Market production was probably desirable for all households regardless of economic orientation, since trade generated incomes to purchase products that were difficult or impossible to produce within the household. In the following sections, we describe each of these activities with more detail.

\section{Plants, Berries, and Handcrafts}

In the interior of northwest Fennoscandia, the growing season lasts approximately from May to September and gets shorter with increased altitude, which occurs with a clear gradient between the eastern boreal forest and the western mountainous region. During the summer, the

${ }^{4}$ Zackrisson et al. (2000). 
short growing season is somewhat compensated by the length of the polar day, as plenty of daylight favors both growth and nutritional content in plants. Sub-zero temperatures, or even snowfalls, are not exceptional during the growing season, but native plants have adapted rather well to the capricious weather. However, frosts in early summer can affect flowering and thus fructification negatively, especially for berry plants, which in turn might reduce the amount of fruit later in the season. For early modern inhabitants, the short growing season meant they only had a few summer months to collect wild plants and berries, and the weather made the returns unpredictable from year to year.

Sources frequently described how early modern inhabitants gathered berries, bark, firewood, wild herbs, roots, and sedges, mostly for their own use but sometimes to sell. Inhabitants collected bilberries (Vaccinium myrtillus), cloudberries (Rubus chamaemorus), crowberries (Empetrum nigrum), and lingonberries (Vaccinium vitis-idaea). ${ }^{5}$ These were either eaten straightaway, served in milk or fish stews, or stored in cool places for later use. With regard to trade, it is stated that fisher households in Ume lappmark could obtain cheese, reindeer calves, or meat from reindeer pastoralist households in return for berries. ${ }^{6}$

Plants were gathered for different purposes. ${ }^{7}$ Some plants were presumably collected because they tasted good and contributed to an otherwise one-sided diet of meat or fish. Among the collected edible plants mentioned in the source material were alpine blue-sow-thistle (Cicerbita alpina), common sorrel (Rumex acetosa), garden angelica (Angelica archangelica), and wild angelica (Angelica sylvestris). As with berries, herbs could be eaten as they were or with milk, or be saved for later use. Some plants were considered medicinal, and could be used to treat a variety of conditions and illnesses. ${ }^{8}$ Within this group, garden angelica fought off colds, mugwort (Artemisia vulgaris) remedied toothaches, tormentil (Potentilla erecta) cured stomach pains, and yarrow (Achillea millefolium) treated small cuts or wounds (Fig. 8.1).

\footnotetext{
5 Graan (1899, p. 42) and Rheen (1897, p. 21).

${ }^{6}$ Lundius (1905, p. 19).

7 Aronsson (2000), Phebe Fjellström (2000), Linnaeus (2003, pp. 91-102), Lundius (1905, p. 11), Rautio (2014, pp. 20ff), Rheen (1897, p. 21), and Svanberg (2000).

${ }^{8}$ Phebe Fjellström (2003, p. 255), Linnaeus (2003, p. 95), and Tunón (2000).
} 


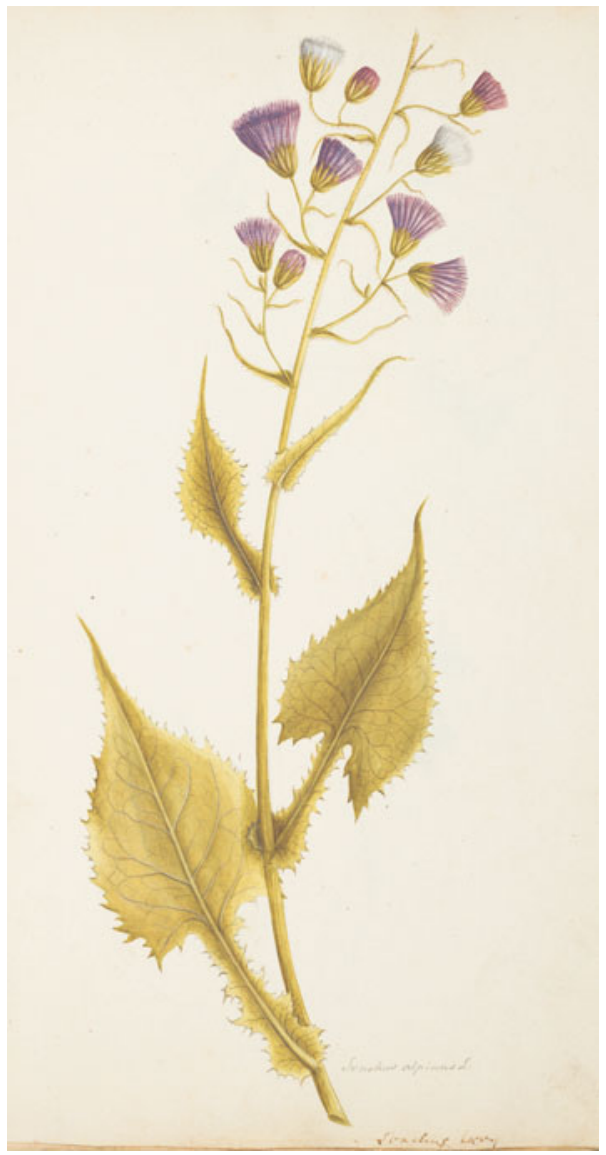

Fig. 8.1 Alpine blue-sow-thistle (Cicerbita alpine), depicted in 1695 (Source Iter lapponicum, Luefsta MS 92, Uppsala University Library, Sweden. Public domain. https://www.alvin-portal.org/alvin/imageViewer.jsf?dsld=ATTACHMENT0028\&pid=alvin-record:162152)

Although berry picking surely was an activity in almost every household, it is elusive in court rulings. Like most ordinary chores, berry picking was rarely a subject of conflict and in the court cases it is only mentioned a few times to contextualize other events. For example, in 1704 a man from Sirkas stated in court that his sister had gone 
missing. ${ }^{9}$ The sister's husband, who was asked about her disappearance, described that she had gone out one morning late in September, just before Michaelmas, to pick bär eller lingon (berries or lingonberries). He had accompanied her to a location roughly one-quarter of a Swedish mile (2 to $3 \mathrm{~km}$ ) from their living grounds, where som mästa bären finnes (most berries were to be found). According to him, she had remained at the berry site and he had gone to search for some lost reindeer. She had not returned home in the evening. The particulars linked to this tragic event contribute useful information about berry picking: it was part of everyday life, it could take place rather late in the season, and inhabitants had comprehensive knowledge about the locations of good berry sites.

When it came to the distribution of rights to resources, berries were hardly ever mentioned in the court material. One exception was in a court ruling from 1770 when a pair of brothers transmitted two lands they had inherited from their father to another user. According to the court records, the lands included two lakes and one bärbacke (berry hill). ${ }^{10}$ It implies that berries belonged to the user of a land, in contrast to present-day Sweden where wild berries are open access.

Other plants were collected for more practical reasons. In late summer, a couple of particular sedge species (Carex sp.) were harvested when the straw had become tall and rich in lignin and therefore durable. After initial clearing from twigs, the sedge was sorted into bundles that were struck against rocks to become soft, and then left to dry. The dried straws were later used as shoe hay in leather boots to keep feet warm and comfortable. ${ }^{11}$ Preparation of shoe hay was probably a time-demanding task since household members had to gather enough to last until the following summer. The ready-made shoe hay could be bartered and, at least in Ume lappmark, fisher households exchanged shoe hay with reindeer pastoralist households in return for reindeer products. ${ }^{12}$

Plant parts that were rich in colorfast natural pigments could also be used to produce dye. The root of tormentil was, for example, used

\footnotetext{
${ }^{9}$ HRA (1704, pp. 819-821).

${ }^{10}$ Hultblad (1968, p. 369, evidence 259b).

${ }^{11}$ Phebe Fjellström (1986, pp. 339-341) and Linnaeus (2003, pp. 90-94).

12 Lundius (1905, p. 30).
} 
to extract pigments to dye wool red. ${ }^{13}$ Fine roots of birch (Betula $s p$.), Norway spruce, or Scots pine were used to twine threads and ropes, and to make baskets. ${ }^{14}$ The roots were dug up in summer when the ground was soft. Before use they would be soaked in water to get rid of dirt, and to become soft and more manageable. Beside roots, bark from some tree species was collected for tanning leather, foremost bark from birch, rowan (Sorbus aucuparia), grey alder (Alnus incana), and sallow (Salix caprea). ${ }^{15}$ The bark was gathered in early summer when the trees' sap rises, since it makes the bark detach easily from the tree trunk. Aside from tanning, Scots pine bark was also used for consumption and for making storage cases. ${ }^{16}$

Raw materials that were amassed by the household were used in production of clothes, tools, or other utensils that the household members needed. It was mainly the women who turned hides from reindeer and other animals into useful garments, such as hats, cloaks, boots, and gloves sewn with threads of twined sinews. In fact, the manufacturing of threads was a handcraft in itself, and the priest Pehr Högström, ${ }^{17}$ who spent time among households in Kaitum in the eighteenth century, described it as an art that was masterly performed mostly by women. Besides garments, a great variety of utensils were handcrafted, such as boats, sleds, chests, boxes, spoons, and baskets. ${ }^{18}$ Rheen described that handcrafts such as cloaks, boots, and gloves also were sold at market. ${ }^{19}$

Based on evidence in the sources, poor households with few reindeer were more involved in handcrafts and collection of plants and berries than rich households. According to Högström, reindeer pastoralist households were less engaged in handcrafting, but poor Sami, forced by necessity, could be quite skilled at handcrafts. ${ }^{20}$ The explanation is

\footnotetext{
13 Linnaeus (2003, p. 59).

14 Phebe Fjellström (2003, p. 272) and Linnaeus (2003, p. 141).

15 Phebe Fjellström (2003, p. 272) and Linnaeus (2003, pp. 28-30).

16 Graan (1899, p. 43), Rautio (2014, pp. 25ff), and Zackrisson et al. (2000).

17 Högström (1747, p. 88).

18 Graan (1899, p. 52), Högström (1747, p. 87), and Rheen (1897, p. 57).

19 Rheen (1897, p. 58).

${ }^{20}$ Högström (1747, p. 87).
} 
probably that poor households had more time and could prioritize gathering and refinement of plant materials since they had few reindeer. For pastoralists, the work-intensive tasks of tending and milking reindeer left little or no time for them.

\section{Cultivation, Livestock, and Caring for Reindeer}

Most early modern households in interior northwest Fennoscandia were non-sedentary, which is linked to their extensive use of natural resources. For these households, mobility was a means to optimize use of relatively low-productivity fishing waters, hunting grounds, and reindeer pastures spread out over large areas. Cultivation on the other hand, rests on a different kind of logic, namely intensive land use that maximizes the use of a constrained area. Prerequisites for successful cultivation are soil preparation, fertilization, watering, and weeding, which meant that gardeners/farmers had to invest quite a lot of energy into a plot of land to get a significant output. Besides access to arable land, cultivation demands access to manure, seeds, tools, etc. Moreover, the cultivator has to tend regularly to the growing plants, from sowing to harvest which demands a sedentary lifestyle, at least during the growing season. Toward the nineteenth century, more and more households began to settle in interior northwest Fennoscandia, and it was not until then that cultivation became more dispersed. ${ }^{21}$ Due to the climatic constraints at these northern latitudes, it is especially challenging to cultivate on open land, and crop production has never prevailed. Sedentary households, instead, continued to rely on a wide range of subsistence activities, such as keeping of livestock, forestry, fishing, hunting, and small-scale reindeer herding.

All the same, it is evident from the sources that cultivation occurred in the inland from time to time. Lundius described, for example, how

\footnotetext{
${ }^{21}$ Josefsson et al. (2014) suggest that records of fossil cereal pollen from northernmost Sweden, Norway, and Finland show that cereal was cultivated among inhabitants there in prehistoric time.
} 
inhabitants in Ume lappmark sometimes dug up small plots in the enclosures where reindeer had been milked in order to sow turnip (Brassica rapa ssp. rapa) seeds. ${ }^{22}$ It was a resourceful cultivation strategy that took advantage of already fertilized and fenced plots. Even a small yield was probably a welcome contribution to the household diet. Turnip cultivation seems especially worthwhile when linked to a statement by Linnaeus, who said that the inhabitants desired turnips so much that they easily would trade a whole reindeer cheese for a single turnip, which he by the way found foolish. ${ }^{23}$ From Torne lappmark, Tornaeus stated that "the settlers in the Lappmark sow a great deal of turnip seed, which frequently succeeds very well and produces a plentiful crop." ${ }^{24}$ Given the many contacts between Sami and neighboring groups, it is not unlikely that Sami would acquire inspiration, cultivation tips, and turnip seeds from non-Sami settlers.

Besides cultivation, some sources also describe how mostly wealthy reindeer pastoralist households kept livestock during summers. ${ }^{25}$ In early summer, these reindeer herders bought cows, sheep, and goats in Norway and took them to the mountains to graze with the reindeer. Like reindeer, livestock was milked daily. Around the time of the first snowfalls in autumn, when accessible grazing for livestock diminished, the animals were slaughtered and the meat stored or consumed. This type of animal husbandry had many similarities to reindeer herding, and could easily be integrated into the households' supply strategy.

The interaction between Sami and other groups also centered around a particular system for management of tame reindeer, so-called skötesrenar. It was a common practice, for example, for Norwegian and Swedish peasants, tradesmen from the coast of the Gulf of Bothnia, and nonSami settlers in the inland to own reindeer that were cared for by Sami pastoralists. In return, reindeer pastoralists got paid with money and products such as salt and flour. According to Hultblad, the custom had

\footnotetext{
22 Lundius (1905, p. 27).

23 Linnaeus (2003, pp. 58 and 60).

${ }^{24}$ Tornaeus (1900, pp. 63-64).

25 Graan (1899, p. 37), Lundius (1905, p. 32), Högström (1747, p. 118), and Rheen (1897, p. 59).
} 
long historical roots. ${ }^{26}$ It was probably an important income source for many Sami households. In 1699, three court rulings in the local court in Jokkmokk concerned relationships between people from Luleå town and Sami in Lule lappmark who took care of, or rented out reindeer. ${ }^{27}$ In two of the cases, the death of a reindeer had sparked a discussion about responsibility and compensation.

\section{Trade and Transports}

Although it was mostly a subsistence economy, trade has long historical roots in the interior of northwest Fennoscandia, as interactions both between local households and with external tradesmen. ${ }^{28}$ Trade implied that households did not have to be entirely self-sufficient, but that they, if they had the means, could barter or buy goods from other producers. In many ways, the seventeenth century was a transitional period with an expansion of trade, and an increased focus on reindeer herding. Around this time, the state had introduced official market places in each lappmark where recurring markets took place in January or February each year. One such marketplace was located in Jokkmokk in Lule lappmark. At these markets, inhabitants sold surplus produce to each other and to non-Sami tradesmen from the nearest Swedish coastal towns. According to the sources, inhabitants primarily sold live reindeer and reindeer meat, reindeer hides and furs, reindeer cheese, and handcrafted products, such as fur parkas, boots, gloves, and cloaks. ${ }^{29}$ They also sold dried fish, furs of wild game, and down and feathers.

The tradesmen traveled to these markets for the sole purpose of doing business with Sami. It was surely the increased wealth among reindeer pastoralist households that made them grasp the opportunity to buy reindeer products and to proliferate from sales to a new and growing

\footnotetext{
${ }^{26}$ Hultblad (1968, pp. 148-150).

27 HRA (1699, pp. 89-90, 100-101).

${ }^{28}$ Hansen and Olsen (2014, pp. 232-243). As discussed in Chapter 4, trade was a prerequisite for the livelihood of early modern Sami households and for the development of reindeer pastoralism.

${ }^{29}$ Ehrenmalm (1743, p. 91) and Rheen (1897, p. 58).
} 
consumer group. The lists of products that merchants took to these markets included alcohol, axes, brass rings, clay tobacco pipes, coins, copper, fabric, fishing tackle, flour, gunpowder, ox and cow hides, iron, knives, lead, needles, rifles, rope, salt, silver, tar, and tobacco. ${ }^{30}$ Aside from written trade lists, pieces of clay tobacco pipes, pottery, and porcelain, as well as needles, metals, and coins which originated from the early modern era, have been found at the ancient market site in Lycksele in Ume lappmark. ${ }^{31}$

The state had awarded Swedish merchants in coastal towns by the Gulf of Bothnia the exclusive privilege to trade with inhabitants in the Swedish lappmark. All trade was, however, not legal, and court cases that deal with illegal trade enable us to study firsthand what inhabitants bought and how they paid for goods. In November and December of 1705, a peasant from Pajala in the parish of Övertornea traveled to the Sami village of Kaitum in Lule lappmark to do business with the inhabitants there. He was not a tradesman from the designated coastal area and, therefore, was not allowed to trade in the lappmark. In total, eight men from Kaitum were mentioned in court rulings to do with illegal trade with the peasant. For example, one man bought an ax and brännvin (hard liquor) that he paid for with härnskor (shoes) and vajrenskinn (reindeer fur). Another man bought an ax that he paid for with three pairs of gloves, and three lispund (around $25 \mathrm{~kg}$ ) of flour that he paid for with a vaja (female reindeer). A third man bought tobacco that he paid for with reindeer fur. A fourth man bought salt that he paid for with gloves. ${ }^{32}$ Although these transactions were illegal, they probably give a valid picture of what kinds of goods inhabitants would buy, and how they would pay for them in legal trade.

Some reindeer pastoralists acted as middlemen or forwarding agents in trade between Swedish and Norwegian merchants. When the reindeer grazed in Norway, or in the mountains on the border, some pastoralists took the opportunity to visit Norwegian markets to do business. These markets took place twice each year: around midsummer and in

\footnotetext{
30 Ehrenmalm (1743, p. 91) and Rheen (1897, p. 59).

${ }^{31}$ Huggert (2009, 2010), and Rydström (2006). The marketplace in Lycksele was in use only until 1785 .
}

32 HRA (1706, pp. 50-51). 
November. Reindeer pastoralists could sell both self-produced goods, such as reindeer hides and meat, and goods they had bought or bartered from Swedish merchants or Sami households in the boreal forest, such as feathers and down. ${ }^{33}$ These middlemen took advantage of the fact that some merchandise, for example, silver, tobacco, and woven wool blankets, were cheaper in Norway. They also brought dried sea fish with them back to Sweden, that they eventually could sell to Swedish merchants.

Most of the barter between households probably took place outside the market on a day-to-day basis whenever people crossed paths. Bartering between local households included, for example, reindeer meat, cheese, shoe hay, berries, dried fish, down, feathers, and turnips. ${ }^{34}$ Some court rulings also give insights into how goods changed hands between households. More specifically, barter is sometimes mentioned in cases that dealt with theft, or when someone had to account for how he or she had obtained a certain food item. As always in court, we cannot decide whether the defendants were telling the truth or not, but the point to make here is that they had to tell a story that aligned with the proper way to go about it in similar situations in order to convince the lay-judges. All lay-judges were well-acquainted with barter and could, probably rather effortlessly, determine if the defendant's story seemed reasonable or not. A court ruling from 1704 about a stolen rana (a woven wool fabric that was used as a cover on the goahte or a blanket) revealed several barter deals. The plaintiff, Anders Nilsson who was the original owner of the stolen rana, had found it at Anders Pålsson's home. Pålsson claimed that he had bartered it from a third person, Tore Andersson, in return for two reindeer. Andersson in turn, claimed that he had gotten the rana from Anders Nilsson (unclear if it intended the plaintiff or someone else by that name) in return for $1 \frac{1}{2}$ riksdaler, 1 reindeer fur, and ten reindeer cheese rounds. $^{35}$

\footnotetext{
33 Ehrenmalm (1743, p. 91), Lundius (1905, p. 40), and Rheen (1897). In a court ruling from 1701 , a man had sold "fresh meat" in Norway in 1699. The meat came from 10 reindeer and had been stored under a stone slab in the mountain in Sweden when it was stolen (HRA 1701, pp. 403-404).

${ }^{34}$ Ehrenmalm (1743, p. 91), Lundius (1905, p. 40), Rheen (1897), and Tornaeus (1900, pp. 63-64).

35 HRA (1704, pp. 810-811). Tore Andersson was convicted.
} 
The routes through interior northwest Fennoscandia were difficult to travel, which made visitors dependent on local guides if they wanted to go there. Many transports were in fact ensured by local households with access to pack and draft reindeer, and Högström in Kaitum even described transports during market season as a good income source for some Sami households. ${ }^{36}$ In addition to draft reindeer, local pathfinders had attained an invaluable sense of direction that guided them along passable routes in rugged terrain in both summer and winter. Most transports of goods were carried out on snow sleds in winter, this circumstance surely contributed to the timing of the annual market in January or February. An important contributing factor was that reindeer pastoralist households grazed their reindeer in the boreal forest that time of year, and thus had temporary settlements near marketplaces. The inland markets would probably have been considerably more difficult for external tradesmen to access without the local reindeer pastoralists with draft reindeer and sleds. In summer, post and people mostly came inland on foot, although boat transports along lakes and rivers surely mitigated transport and travel.

Parallel with the market, when almost all inhabitants in the lappmark were gathered in the same place at the same time, the state took the opportunity to collect the yearly tax, and to have proceedings in the local court. Local inhabitants, therefore, also transported official representatives from the state, such as the bailiff, judge, and court clerk. ${ }^{37}$ These transports were considered duties and stood in relation to the household's status or economic position. The duties also included transports of priests and other church staff year-round. The duty to transport officials could be unpopular, as a court record from 1706 shows. The case concerned Lars Nilsson in Tuorpon, who for many years had been defiant of the order to let his reindeer transport state representatives. The länsman (sheriff) related to the court that Nilsson had told him that he would rather accept a fine than perform these transports, and when he at times had sent reindeer to do transports, they turned out to be incapable and useless as draft animals. His verdict was to pay a fine in both

\footnotetext{
36 Högström (1747, p. 86).

37 Fellman (1910, p. 347).
} 
reindeer and cash and he was told that if he continued to disregard his transport duties, he would be penalized even harder. ${ }^{38}$ This was not the first time the court fined a person for refusing to do transport duties. In 1704, Olof Joensson in Jokkmokk was fined, ${ }^{39}$ and the same year Lars Nilsson in Tuopon was convicted. Henrik Eriksson in the same village was fined for twice neglecting to do his duties. ${ }^{40}$ In some places, such as Nasafjell in Pite lappmark, inhabitants could also have duties related to mining transports. Although these transports provided incomes, they were mostly seen as unwelcome and dreaded burdens by the inhabitants.

\section{Relative Importance of Various Subsistence Activities}

Both reindeer pastoralist households and fisher households took part in various gathering activities, and sold products that were manufactured from gathered resources. Even so, gathering seems to have been more important for fisher households. Among reindeer pastoralist households, social stratification likely gave rise to varying economic strategies within the group. For example, poor households appear to have been more active in handcrafting, fishing, and hunting. The rational explanation here is probably that the poor needed several income sources to make ends meet.

The illustration in Fig. 8.2. shows that households in interior northwest Fennoscandia were engaged in a wide range of economic activities, such as reindeer herding, fishing, hunting, handcrafting, cultivation, livestock keeping, gathering, trade, and transport. Diversification of activities was part of an economic system and not just occasional tasks performed randomly. However, this was not equally distributed between pastoralist and fisher households.

\footnotetext{
38 HRA (1706, pp. 53-54).

${ }^{39}$ HRA (1704, p. 812).

${ }^{40}$ HRA (1706, p. 59).
} 

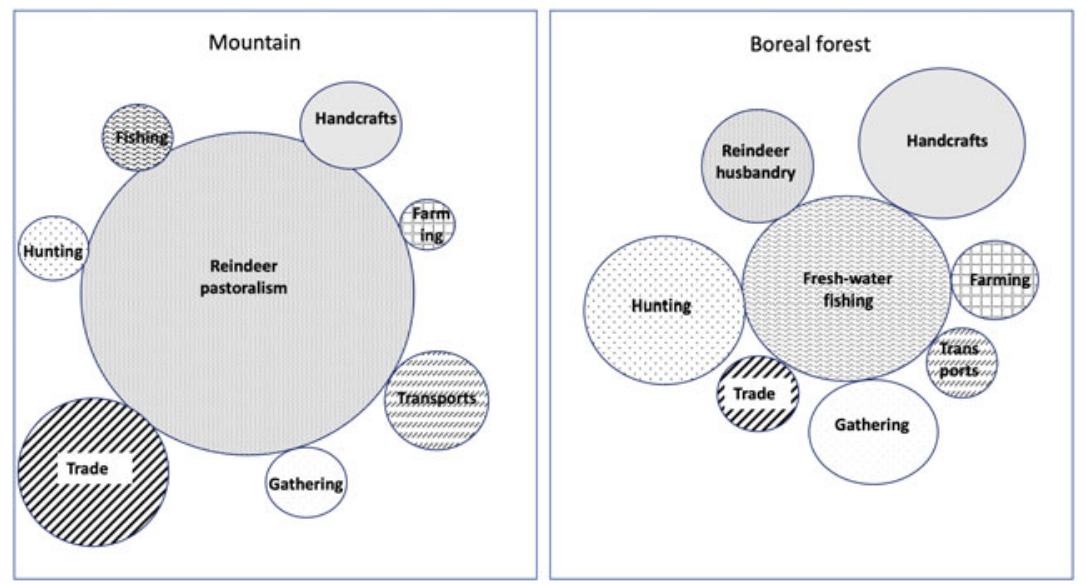

Fig. 8.2 Model showing the relative importance of various subsistence activities in pastoralist and fisher households in interior northwest Fennoscandia in the seventeenth and eighteenth centuries (Source Adapted from E.-L. Päiviö [2017, p. 155, with permission])

\section{References}

Aronsson, Kjell-Åke. Å. 2000. Användning av ängssyra (Rumex acetosa) bland samerna. In Samisk etnobiologi Människor, djur och växter $i$ norr, ed. Ingvar Svanberg and Håkan Tunón, 253-258. Nora, Sweden: Bokförlaget nya Doxa.

Bjørklund, Ivar. 2013. Domestication, reindeer husbandry and the development of Sámi pastoralism. Acta Borealia 30( 2): 174-189. https://doi.org/ 10.1080/08003831.2013.847676.

Ehrenmalm, Arwid. 1743. Resa igenom Wüster-Norrland til Asehle lappmark, anstäld uti julii månad 1741. Stockholm. Available page by page at http:// runeberg.org/resawenoas/index.html.

Fellman, Isak. 1910. Handlingar och uppsatser angående Finska Lappmarken och lapparne. Helsinki: Finska Litteratursällskapets Tryckeri.

Fjellström, Phebe. 1986. Samernas sambälle $i$ tradition och nutid, 2nd ed. Stockholm: Norstedt 
Fjellström, Phebe. 2000. Fjällkvannen (Angelica archangelica) i samisk tradition. In Samisk etnobiologi, ed., Ingvar Svanberg och Håkan Tunón, 241-252. Nora, Sweden: Nya Doxa.

Fjellström, Phebe. 2003. Etnologisk kommentar. In Iter Lapponicum. Lappländska resan 1732, II Kommentardel, ed. Carl Linnaeus, 250-287. Umeå, Sweden: Kungl. Skytteanska Samfundet.

Graan, Olaus. 1899. Relation, eller en fulkomblig beskrifning om lapparnas ursprung, så wähl som om heela dheras Lefwernes Förehållande. Uppsala, Sweden: Harald Wretmans tryckeri.

Hansen, Lars Ivar, and Bjørnar Olsen. 2014. Hunters in transition: An outline of early Sámi history. Leiden, the Netherlands: Brill.

Högström, Pehr. 1747. Beskrifning öfwer de til Sweriges krona lydande lapmarker. Stockholm: Salvius. http://urn.kb.se/resolve?urn=urn:nbn:se: umu:eod-114.

Huggert, Anders. 2009. Danska mynt funna på kåtaplats i Tärna socken, Lappland. Svensk Numismatisk Tidskrift 7: 159-161.

Huggert. Anders. 2010. Kyrk- och marknadsplatsen Lyksälie under 16001700-talen. Svensk Numismatisk Tidskrift 1: 6-10.

Hultblad, Filip. 1968. Övergång från nomadism till agrar bosättning i Jokkmokks socken. PhD dissertation, Uppsala University.

Josefsson, Torbjörn, Per H. Ramqvist, and Greger Hörnberg. 2014. The history of early cereal cultivation in northernmost Fennoscandia as indicated by palynological research. Vegetation History and Archaeobotany 23: 821-840. https://doi.org/10.1007/s00334-014-0446-2.

Linnaeus, Carl. 2003. Iter Lapponicum: Lappländska resan 1732. I. Dagboken. Umeå, Sweden: Kungl. Skytteanska Samfundet.

Lundius, Nicolai. 1905. Descriptio Lapponia. Uppsala, Sweden: Harald Wretmans tryckeri.

Päiviö, Eva-Lotta. 2017. Livelihood diversification in early modern Sami households in northern Sweden. In Integrated peasant economy in a comparative perspective: Alps, Scandinavia and beyond, ed. Aleksander Panjek, Jesper Larsson, and Luca Mocarelli, 137-159. Koper, Slovenia: University of Primorska Press.

Panjek, Aleksander, Jesper Larsson, Luca Mocarelli, eds. 2017. Integrated peasant economy in a comparative perspective: Alps, Scandinavia and beyond. Koper, Slovenia: University of Primorska Press. https://www.hippocampus. si/ISBN/978-961-7023-02-2.pdf. 
Rautio, Anna-Maria. 2014. People-plant interrelationships: Historical plant use in native Sami societies. PhD dissertation, Sveriges lantbruksuniversitet, Umeå, Sweden. http://urn.kb.se/resolve?urn=urn:nbn:se:slu:epsilon-e-2168. Rheen, Samuele. 1897. En kortt relation om Lapparnes lefwarne och sedher, wijd-skiepellsser, sampt i många stycken grofwe wildfarellsser. Uppsala, Sweden: Harald Wretmans tryckeri.

Rydström, Gunhild. 2006. Det äldsta Lycksele - Öhn: rapport över genomgång och bearbetning av fyndmaterial från undersökningar åren 1949-2001, rä̈ nr 343, Gammplatsen, Lycksele socken, Lappland. Lycksele, Sweden: Skogsmuseet.

Svanberg, Ingvar. 2000. (Lacta Alpina) i Samiskt kosthåll. In Samisk etnobiologi Människor, djur och växter $i$ norr, ed. Ingvar Svanberg and Håkan Tunón, 259-265. Nora, Sweden: Bokförlaget nya Doxa.

Tornaeus, Johannes. 1900. Berättelse om Lapmarckerna och Deras Tillstånd. Uppsala, Sweden: Harald Wretmans tryckeri.

Tunón, Håkan. 2000. Botemedel inom samisk medicin. In Samisk etnobiologi Människor, djur och växter i norr, ed. Ingvar Svanberg and Håkan Tunón, 126-163. Nora, Sweden: Bokförlaget nya Doxa.

Zackrisson, Olle, Lars Östlund, Olavi Korhonen, and Ingela Bergman. 2000. The ancient use of Pinus sylvestris L. (Scots pine) inner bark by Sami people in northern Sweden, related to cultural and ecological factors. Vegetation History and Archaeobotany 9 (2): 99-109. https://doi.org/10.1007/BF0130 0060 .

\section{Archival Sources}

Härnösand Regional Archive (HRA):

Rulings in Jokkmokks District Court, Sweden, 1689-1780. 
Open Access This chapter is licensed under the terms of the Creative Commons Attribution 4.0 International License (http://creativecommons.org/ licenses/by/4.0/), which permits use, sharing, adaptation, distribution and reproduction in any medium or format, as long as you give appropriate credit to the original author(s) and the source, provide a link to the Creative Commons license and indicate if changes were made.

The images or other third party material in this chapter are included in the chapter's Creative Commons license, unless indicated otherwise in a credit line to the material. If material is not included in the chapter's Creative Commons license and your intended use is not permitted by statutory regulation or exceeds the permitted use, you will need to obtain permission directly from the copyright holder.

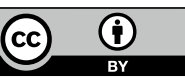

